\title{
Partisipasi Publik dalam Proses Menuju Indonesia Baru Evaluasi Terhadap Perkembangan Pemerintahan
}

\author{
Leo Agustino
}

\begin{abstract}
When Soeharto's nulo begin, in public administration sphere, Indonesia have been emphasizing too much in accommodate the interest of power elite rather than a public interest. It made a public administrator acted like an elite interest want. This image caused a lot of perspectives that public administration in Indonesia do not exist properly. Cause they acted and worked as an "Abdi Negara" rather than "Abdi Masyarakat". The ongoing of political constelation in 1998 was giving a way to introduce a new paradigm of administration-mainstream from the state-oriented-administration to the public-oriented-administration. For that reason, public participation in public administration reform is a realistic idea to be impelemented.
\end{abstract}

Kata Kunci: publik, administrasi . publik, dan partisipasi publik

$D$ eformasi dipelbagai bidang di Indone Isia yang telah berjalan enam tahun awalnya dimulai dengan adanya paradoks antara tuntutan akan kehidupan yang lebih baik dan demokratiș, di satu sisi, dan situasi anarkis di sisi lainnya. Tuntutan yang kuat akan kehidupan yang demokratis muncul sebagai konsekuensi. logis atas lahirnya kehidupan baru akibat perilaku politik rezim terdahulu yang banyak mengabaikan, melanggar, atau bahkan menginjak-injak hak-hak warga Negara (HAM). Kesadaran bahwa relasi sosial, ekonomi, maupun relasi kekuasaan yang dibangun selama ini dirasakan oleh banyak orang terlalu timpang, angkuh, dan represif. Sedangkan, siatuasi anarkis muncul sebagai manifestasi. agresifitas dari rasa putus asa dan ketidakberdayaan sebagian besar anggota masyarakat ketika berhadapan dengan struktur-struktur yang arogan. Tuntutan memenuhi kebutuhan-kebutuhan hidup minimum yang sangat mendesak, disparitas yang sangat tajam, serta hancurnya kepastian normatif dan kepantasan berperilaku didalam masyarakat, menjadi ladang yang subur bagi berbagai kerusuhan sosial. Situasi anomik semacam ini sangat lazim terjadi pada masyarakat yang mengalami perubahan sosial yang.sangat cepat dan mendadak ?

Pertanyaan yang selalu muncul adalah akankah demokrasi mengkristal dalam kehidupan bemegara-bangsa di Indonesia di masa yang akan datang, ataukah anarki akan terus merajálela sehingga memunculkan perang saudara dan disintegrasi bangsa? Jawaban terhadap pertanyaan tersebut di muka, tidaklah mudah. Namun

1 Huntington, Samuel P. (1971). "Change to Change: Modernization, Development, and Politics". Comparative Politics, III: 283-322, April 1971. 
pengalaman empiris menunjukkan, bahwa suatu negara-bangsa dapat saja mulai dengan dengan mencanangkan proses demokratisasi setelah tumbangnya rezim otoriter, tetapi tidak semua negara-bangsa yang melakukan demokratisasi berhasil sampai pada demokrasi yang dicitakan. ${ }^{2}$ Tidak ada jaminan bahwa rezim baru yang berkuasa dapat bertahan, stabil, dan mampu mengantarkan negara-bangsanya menuju ide demokrasi yang dicitakan bersama. Tumbangnya pemerintahan Nigeria pada tahun 1983 dan Sudan tahun 1989 merupakan contoh yang dapat dijadikan pelajaran. Di Angola, fase transisi menuju demokrasi berakhir dengan pecahnya perang saudara dan berlanjut pada rezim yang otoriter. Demokratisasi adalah proses bertingkat-tingkat dimana terdapat kemungkinan bagi setiap negara-bangsa untuk gagal di setiap tingkatan sepanjang garis kontinum dari otoritarianisme sampai dengan tahap demokrasi yang baru. ${ }^{3}$

Pengalaman Indonesia di masa lalu, baik di bawah rezim Orde Lama maupun di bawah pemerintahan Orde Baru, merupakan petunjuk betapa sulitnya jalan menuju masyarakat dan negara-bangsa yang demokratis. Jika demikian halnya, mengapa beberapa negara berhasil mencangkok demokrasi setelah runtuhnya rezim otoriter, sementara beberapa negara lainnya gagal? Dan, mengapa proses demokratisasi di beberapa negara berhasil sampai ke tahap mengkristalnya demokrasi baru, sementara yang lainnya mandeg atau bahkan berantakan pada tahap-tahap awal? Setelah membandingkan dengan mengkaji beberapa kasus, Casper dan Taylor berpen dapat, bahwa tahap pencangkokan demokrasi baru merupakan separuh dari proses demokratisasi. Hal ini tidak dapat diasumsikan bahwa demokrasi akan tumbuh dan berkembang dengan sendirinya. Menurut mereka ada dua langkah penting yang harus dilakukan agar atau negara-bangsa dapat sampai pada kehidupan demokratis yang dicitakan. Pertama, langkah jangka pendek yang berkaitan dnegan pencarian jalan keluar bagi kekuatan-kekuatan yang masih mndukung rezim lama; dan, kedua, adalah langkah jangka panjang yang difokuskan pada proses konsolidasi demokrasi baru tersebut. Kerangka tersebut bukanlah resep yang dapat mentransformasi otoritarianisme dan situasi anarkis saat ini menjadi kehidupan yang harmonis dari demokratis dalam sekejap mata, semalam, atau bahkan dalam hitungan bulan. Akan tetapi, melalui temuan Casper dan Taylor bangsa indonesia dapat memompa optimisme dari mana usaha harus dimulai agar proses reformasi yang tengah bergulir tidak berakhir dengan kembalinya kekuasaan negara yang begitu besar sehingga warna otoritarianisme atau bahkan fasis menjadi keadaan nyata sekali lagi di negeri ini.

\section{Kon'struksi Bangunan Administrasi Publik di Indonesia}

Administrasi publik seperti yang dirumuskan oleh Pfiffner dan Presthus adalah sebuah disiplin ilmu yang terutama mengkaji cara-cara untuk mengimplementasikan nilai-nilai politik. Dimock dan Dimock ${ }^{4}$ merumuskan tugas administrasi publik adalah, "...the accomplishement of politically determined objectives...." Hal tersebut sejalan dengan gagasan awal

2. Snyder, Jack. (2003). Dari Pemungutan Suara ke Pertumpahan Darah: Demokratisasi dan Konflik Nasionalis. Jakarta: Gramedia.

3. Casper, Gretchen, and Michelle Taylor. (1996). Negotiating Democracy: Transition from Authoroitarian Rule. Pittsburgh: Pittsburgh Press.

4. Dimock and Dimock. (1969). Public Administration. New York: Rinehart \& Co. 
Woodrow Wilson yang dianggap banyak pihak sebagai orang yang membidani lahirnya ilmu Administrasi Publik Modern di Amerika Serikat. Wilson mengemukakan bahwa disiplin administrasi publik modern merupakan produk perkembangan ilmu politik. Namun Wilson mengusulkan adanya pemisahan disiplin administrasi publik dari ilmu politik. Gagasan ini kemudian dikenal dengan sebagai dikotomi politik-adminisrasi. IImu Administrasi Publik, menurut Wilson lebih lanjut, berkaitan dengan dua hal utama yaitu: what government can properly and successfully do? Dan How it can do proper thins with themost possible efficiency and at least possible cost either of money or of money? Dengan kata lain administrasi publik berurusan dengan persoalan bagaimana pemerintah to do the right things dan to do things right. Jika yang pertama telah ditentukan secara politis, maka tugas administrasi publik selanjutnya adalah menjalankan agenda politik yang telah ditentukan secara efisien. Itulah tugas dasar administrasi publik modern menurut penggagasnya.

Persoalan sekarang adalah dapatkah administrasi publik di Indonesia menjalankan agenda politik yang telah ditetapkan dalam menciptakan masyarakat dan negara-bangsa yang lebih demokratis? Bukankah birokrasi sendiri merupakan bagian dari masalah ketimbang sebagai bagian dari pemecahan masalah? Jawaban empirik terhadap apriori tersebut tidaklah selalu positif, peran administrasi publik dalam menyelesaikan berbagai masalah yang berkaitan dengan demokratisasi cukup signifikan. Di Taiwan, misalnya, seperti juga di negara-negara yang sedang berkembang lainnya, pemerintah berurusan dengan masalah bagaimana merekonsiliasi pertentangan antara budaya tradisional, demokrasi, dan industrialisasi.Untuk menghadapi persoalan tersebut para ahli administrasi publik membantu para pengambil keputusan di Taiwan untuk menyelesaikan reformasi administratif yang kompleks dengan menggunakan pendekatan perencanaan strategis. ${ }^{5}$ Atau kasus di Korea Selatan, reformasi aparat administrasi bukanlah topik utama yang menarik. Masyarakat lebih tertarik pada dua hal,yakni: demokratisasi politik dan pengadaan public goods dan service providing yang disalurkan langsung pada mereka. Namun akhirnya baik proses demokratisasi politik maupun kuantitas dan kualitas keluaran pemerintah dalam pengadaan barang-barang dan jasa tersebut sangat tergantung pada sistem administrasi publik yang berlaku. Reorganisasi administratif yang dilakukan oleh Kim Young-Sam, pemerintahan sipil pertama setelah 30 tahun dipimpin oleh rezim militer, mempunyai dampak yang sangat signifikan bagi perkembangan ekonomi Korea Selatan.

O'toole ${ }^{6}$ membuat sebuah kesimpulan bahwa administrasi publik yang berkembang saat ini sudah tak terlalu hirarkis dan parokial, tetapi lebih mirip jejaringan (network). Kecenderungan ini mempunyai implikasi yang sangat penting dan positif terhadap perkembangan demokrasi, termasuk tanggung jawab yang berubah terhadap kepentingan publik, terhadap pemenuhan preferensi masyarakat, dan terhadap perluasan liberalisasi politik, dan

5. Sun, Tung-Wen and John J. Gargan. (1996). A Strategic Perspective on Public Administration Problems in Taiwan. Asian Journal of Public Administration 18(1): 96-118, June 1996.

6. O'toole, Laurence., Jr. (1997). the Implications for democracy in a Networked Bureucratic World. Journal of Public Administration Reaserch and Theory 7(3): 443-459, July 1997. 
tingkat kepercayaan publik (high-trust society, meminjam istilah F. Fukuyama). Administrasi publik yang berbentuk jejaringan dapat mengatasi hambatan menuju pengelolaan yang demokratik, dan dapat membuka kemungkinan-kemungkinan untuk dilakukannya penguatan pemerintahan yang bergantung pada nilai-nilai dan tindakan-tindakan administrasi publik. Hal tersebut dikemukaan O'toole dalam rangka mengenang Dwight Waldo yang pernah mengemukakannya lebih dulu, jika administrasi adalah inti dari pemerintahan, maka teori demokrasi seharusnya mencakup pula materi administrasi.

Optimisme tentang gerakan reformasi administrasi publik yang paling popular saat ini muncul dalam kemasan reinventing government sebagai kristalisasi pengalaman dan praktik administrasi publik di Amerika Serikat.Mereka berpendapat bahwa institusi-institusi administratif yang didirikan dalam kerangka birokrasi dengan model komando dan pengawasan telah berubah secara signifikan selama Abad ke-20. Birokrasi jenis ini tidak lagi efektif dan bahkan sangat ketinggalan zaman. Oleh karena itu, birokrasi di Amerika Serikat harus lebih berkarakter wirausaha (entrepreneur). Sebagai akibatnya perlu dilakukan reformasi struktur-institusi administrasi publik yang ada.

Akan tetapi tidak semua pengalaman negara lain bernada optimistik.Kritik terhadap pelaksanaan reinventing goverment adalah salah satu contohnya. Dengan menggunakan meta-analisa terhadap 170 kasus dari 104 Biro Federal, Wolf menyimpulkan bahwa jalan menuju efektivitas birokrasi dari biro-biro pemerintah Federal tidaklah berbeda; tiada habisnya dan lebih bersifat politis daripada kisah keberhasilan reinventing government seperti yang umumnya dipercaya mayoritas orang.
Kelemahan pendekatan kewirausahaan terhadap administrasi publik juga ditunjukkan oleh Cope. ${ }^{8}$ Cope berpendapat bahwa banyak konsep dan teknik yang berhubungan dengan reformasi birokrasi sekarang ini sarat dengan berbagai implikasi terhadap responsivitas politik. Reviewterhadap kerja pegawai, terbukti mampu memperkuat birokrasi dan pejabat terpilih, namun ternyata memperlemah responsivitas politik. Demikian pula halnya dengan sistem keuangan. Dengan mengadopsi pendekatan kewirausahaan terhadap administrasi publik mungkin dapat meningkatkan jumlah pendapatan, tetapi hal tersebut akan mengurangi tingkat responsivitas pelayanan. Penekanan terhadap pelayanan pelanggan dapat berarti hanya memperhatikan individuindividu tertentu, sementara pelayanan pada warga masyarakat berarti meningkatkan responsivitas pada publik. Kemitraan sektor publik dengan swasta yang ditawarkan oleh model di atas menimbulkan masalah etik. Ghere (1997) menyimpulkan bahwa dalam gema reinventing govemment ada indikasi bahwa etika administrasi publik terlupakan. Ghere melakukan studi kasus tentang kemitraan antara country government dengan local chamber of commerce dari dua perspektif,yaitu: standar moral pribadi dan etika kebijakan. Kasus ini membuktikan adanya penyalah-gunaan keuangan publik dalam kemitraan tersebut.

Nada pesimistik pun muncul dalam situasi di mana administrator publik sama

7. Wolf, Patrick. (1997). 'Why Must we Invent the Federal Government? Putting Historical Development Claims to the Rest". Journal of Public Administration Reaserch and Theory 7(3): 353-388, July 1997.

8. Cope, Glen Hahn. (1997). Bureaucratic reform and Issues of Political responsiveness. Journal of Public Administration Reaserch and Theory 7(3): 461-471, July 1997. 
sekali tidak dapat diharapkan menjadi katalisator dalam proses demokratisasi. Di negara-negara Afrika Sub-Sahara, seperti juga di tempat lain ketika rezim militer menguasai pemerintahan.Rezim militer memerintah dengan sistem komando, dengan melarang partai-partai politik untuk berkembang dan bermetamorfosa, sampai membekukan konstitusi dan melumpuhkan lembaga legislatif. Sebagai akibatnya adalah tidak ada saluran struktural politik bagi warga negara pada proses pengambilan keputusan. Penguasa militer biasanya memperoleh masukan (input) bagi proses perumusan dan pengambilan dengan cara mengangkat elite politik sipil. Hal tersebut dilakukan sebagai respon terhadap tuntutan transisi kepada pihak sipil dan sebagai teknik politik untuk melakukan sipilisasi rezim militer. Pola empiris menunjukkan bahwa keterlibatan dalam rezim militer merupakan prediktor bahwa rezim tersebut akan mengikuti aturan militer.Dalam konteks inilah administrasi publik tidak kondusif bagi proses kristalisasi demokrasi tetapi menjadi katalisator bagi pelanggengan pemerintah yang berkuasa (dengan otoriter).

Persoalan demokratisasi di Indonesia sampai derajat tertentu mempunyai kemiripan dengan apa yang terjadi dinegaranegara Afrika Sub-Sahara tersebut, di mana masyarakat sipil, yang dianggap sebagai avangarde demokrasi secara substansial dan massif mengadopsi sistem komando militer, termasuk juga dalam sistem pendidikan di sekolah-sekolah dan di rumah tangga. Hampir seluruh sistem dirancang untuk menjamin pelanggengan kepentingan elite politik yang berkuasa, termasuk juga rancangan struktur-kultur maupun aktor administrasi publik, sehingga tidak heran apabila administrasi publik di Indonesia lebih berorientasi pada kekuasaan daripada kepada publik. Lemahnya orientasi administrasi publik Indonesia kepada publik berakar jauh dalam pengalaman historis negara-bangsa Indonesia sejak zaman prakolonial sampai masa Orde Baru di bawah mantan presiden Soeharto. Oleh karena itu, reformasi administrasi publik di Indonesia di mulai dengan merevitalisasi konsep publik baik dalam pemikiran maupun dalam praktik administrasi publik sehari-hari.

\section{Konsep dan Perspektif "Publik" pada Perubahan Zaman}

Pertanyaan pertama yang harus dijawab ialah apa dan siapa yang dimaksud dengan publik? Dalam percakapan sehari-hari kata publik mempunyai dua arti yang berbeda. Pertama, public diartikan sebagai negara atau pemerintah seperti dalam terjemahan Public Administration menjadi Administrasi Negara.Kedua,kata publiksebagai padanan dari kata umum seperti dalam kata public telephone (telepon umum), public transportation (transportasi umum), dan atau public interest (kepentingan umum). Sehubungan dengan biasnya pemaknaan mengenai arti publik tersebut, mungkin perlu pula diusulkan pembakuan istilah administrasi publik untuk mengganti administrasi negara dengan harapan bahwa kepentingan umum akan menjadi perhatian utama (main concern) dari administrasi publik, baik pada aras konsep maupun pada tataran praksis, dan bukan kepentingan kekuasaan negara seperti yang selama ini terjadi.

Pengertian istilah publik dapat ditelusuri menurut asal katanya (secara etimologis). Dalam bahasa Inggris, kata publik (public) dapat ditemukan dalam dua bentuk. Pertama, sebagai kata benda (the public) yang berarti the community in general atau part of community having a particular interest in common. Kedua, sebagai kata sifat (public) yang dapat berarti concerning 
people in general atau provided, especially by central or local government, for the use of people in general atau of or engaged in affairs, entertainement, service, etc. of the people atau open or known to people in general. Dari pengertian tersebut dapat dimengerti secara garis besar, bahwa kata publik dalam bahasa Inggris sangat erat berhubungan dengan segala sesuatu yang menyangkut masyarakat atau orang banyak seperti yang juga terkandung dalam kosa kata bahasa Indonesia.

Dilihat dari sejarah perkembangannya, pengertian klasik dari kata publik dalam bahasa Inggris muncul dari dua sumber. Pertama, berasal dari bahasa Yunani, $p u-$ bes, yang berarti kedewasaan; baik kedewasaan fisik, emosional, maupun intelektual. Dalam khazanah sosiologi dan psikologi, maka pubes -yang kemudian diistilahkan dengan nama puberdimengerti sebagai suatu tahapan kehidupan sosial seorang manusia, yaitu masa transisi yang ditandai dengan adanya perubahan seorang individu dari yang awalnya mementingkan diri sendiri (selfcentered individuals) ke arah usaha memandang dan memperhitungkan orangorang di luar dirinya. Dalam masa ini, seorang individu mulai berminat untuk mengerti kehidupan orang lain atau memahami akibat-akibat dari pelbagai tindakan yang dilakukannya -terhadap orang lain atau sebaliknya. Kedua, kata publik yang berasal juga dari Yunani, koinon yang diadopsi ke dalam bahasa Inggris menjadi commonyang menekankan tentang pentingnya suatu hubungan (relationship) antarindividu. Kedua pengertian tersebut di muka dua pengertian kata publik seperti yang telah di bahas di muka.Kata publik pertama-tama dapat dimengerti sebagai benda (things) apabila hal tersebut menyangkut suatu keputusan publik. Dan kedua, kata publik dapat berarti suatu kemampuan (capacity) apabila hal tersebut menyangkut kemampuan untuk berfungsi secara publik, yaitu kemampuan untuk berhubungan dengan orang lain dan kemampuan untuk mengerti hubungan antara tindakan-tindakan seorang individu dengan akibat yang ditimbulkannya bagi orang lain secara komprehensif.

\section{Perspektif Publik Frederickson}

Frederickson ${ }^{9}$ menjelaskan lima model formal yang berkaitan dengan kedudukan konsep publik yang umum digunakan dalam ilmu-ilmu sosial untuk dikaji kembali dalam rangka merevitalisasi konsep tersebut. Dengan kajian tersebut diharapkan muncul suatu perspektif baru yang menjadi esensi administrasi publik modern.Kelima perspektif publik tersebut adalah sebagai berikut:

Pertama, perspektif pluralis (the pluralist perspective). Perspektif ini memandang publik sebagai konfigurasi dari berbagai kelompok kepentingan (interest group). Menurut pendukung perspektif ini setiap orang mempunyai kepentingan yang sama akan bergabung satu sama lain dan membentuk suatu kelompok.Dalam perkembangan selanjutnya, kelompokkelompok kepentingan tersebut berinteraksi dan berkompetisi untuk memperjuangkan kepentingan individu-individu yang mereka wakili,khususnya dalam konteks pemerintahan. Pandangan demikian bukalah tanpa kelemahan.Ada beberapa kritik yang dilontarkan pada kaum pluralis. Paling tidak ada tiga persoalan yang sering dilontarkan. Pertama, sistem checks and balances dalam sistem demokrasi yang merupakan model ideal kaum pluralis sering memper-

9. Frederickson, George. (1997). the Spirit of Administration. San Fransisco: JosseyBass. 
lambat kinerja pemerintahan. Hal tersebut terjadi karena setiap keputusan yang diambil membutuhkan konsensus dari pelbagai kelompok kepentingan yang diwakili oleh pemimpin mereka. Dan ini memakan waktu yang tidak sebentar. Kritik kedua, kaum pluralis mengandalkan sistem perwakilan. Mereka mengasumsikan bahwa setiap kepentingan individu dapat diwakili oleh kelompokyang biasanya berarti diwakili oleh pemimpin kelompok yang bertindak untuk dan atas nama publik yang diwakilinya. Prinsip perwakilan yang demikian, mengundang persoalan, sejauhmana konsep publik, yakni berbagai kepentingan individu yang beragam dapat dimunculkan dari suatu sistem perwakilan. Kritik terakhir, ketiga, berkaitan dengan masalah efisiensi dan prinsip ekonomi yang merupakan esensi dari administrasi publik yang ideal.

Pandangan kaum pluralis ini sering dipandang tidak memadai untuk merepresentasikan konsep publik, karena dalam praktik isu yang diangkat untuk diperjuangkan seringkali bukanlah merupakan isu yang menjadi perhatian orang banyak. Melainkan dipilih berdasarkan kepentingan kelompok yang dominan. Isu-isu yang tidak menguntungkan secara ekonomis atau politis bagi kelompok tertentu, misainya, tidak akan muncul ke permukaan. Sebaliknya masalah yang sebenarnya banyak perhatian publik, seperti kemiskinan, tidakmenjadi agenda perjuangan para wakil publik karena tidak menjadi perhatian para wakil kelompok kepentingan tersebut. Sementara sering terjadi isu-isu lain yang sebenarnya lebih besifat terbatas muncul lebih mengemuka karena hal tersebut menyangkut kepentingan individu atau kelompok tertentu yang memiliki pengaruh yang kuat. Dengan demikian konsep publik masih sangat sulit digali melalui pemahaman perspektif ini.
Kedua, perspektif pilihan publik, the public choice perspective. Secara umum dapat dikatakan bahwa perspektif ini berakar pada tradisi pemikiran utilitarian yang sangat menekankan pada soal kebahagiaan dan kepentingan individu. Tradisi pemikiran ini tidak terlalu memperhatikan secara khusus nilai-nilai bersama dalam komunitas, termasuk hal-hal yang berkaitan dengan etika.Menurut salah satu pendukung utamanya, Jeremy Bentham, kepentingan komunitas hanyalah merupakan penjumlahan dari kepentingan-kepentingan individu yang membentuknya. Dalam pemikirannya, masyarakat terdiri dari individu-individu yang bertindak rasional di mana setiap tindakannya selalu didorong oleh tujuantujuan (goal directed) dan selalu memilih alternatif-alternatif yang paling menguntungkan bagi dirinya. Pandangan utilitarian ini memandang publik seolah-olah sebagai konsumen dalam pasar. Dengan kata lain perspektif ini mencoba mengaplikasikan prinsip-prinsip ekonomi pasar ke dalam sektor publik. Asumsi metodologis utama dari pandangan ini adalah bahwa tindakan publik harus dimengerti sebagai tindakan individual yang termotivasi oleh kepentingan yang berbeda-beda satu dengan yang lainnya. Menurüt mereka tugas pemerintah dan masyarakat adalah menyediakan lingkungan yang stabil sehingga pilihanpilihan dapat dilakukan dengan bebas.

Seperti juga pandangan pluralis, the public choice perspective cenderung tidak memberikan perhatian yang cukup terhadap mereka yang kurang memiliki hak khusus dalam masyarakat. Jika seseorang memiliki sarana yang dibutuhkan, termasuk penguasaan informasi, maka orang tersebut akan dengan mudah dapat mengarahkan public choice. Sebagai akibatnya, institusi-institusi pemerintahan yang demokratis akan sangat tergantung pada dukungan dari mereka yang 
diperintah. Namun dalam kenyataannya, publik biasanya tidak akan bekerja sama dalam melaksanakan keputusan-keputusan sulit, terutama yang membutuhkan pengorbanan, apalagi jika mereka tidak memiliki kepercayaan pada institusi pemerintahan dan pada pejabat-pejabat yang diangkat. Persoalan lebih lanjut adalah, bahwa sikap para pejabat yang cenderung menghilangkan kepercayaan publik terhadap pemerintah.Dengan demikian usaha penggalian konsep publik dari perspektif ini pun merupakan suatu keniscayaan.

Ketiga, perspektif legislatif, the legislative perspective. Dalam kenyataan, kebanyakan pemerintahan yang bersifat demokratis menggunakan sistem perwakilan tidak langsung. Seperti juga pandangan perspektif pluralis, asumsi dasar yang dianut adalah bahwa setiap pejabat diangkat untukmewakili kepentingan publik. Dengan adanya pengangkatan tersebut mereka memiliki legitimasi untuk mewujudkan perspektif publik di dalam administrasi publik. Dengan demikian pejabat-pejabat yang diangkat tersebut dianggap sebagai manifestasi tunggal dari perspektif publik. Meskipun pandangan ini merupakan pandangan yang dianggap realistik dan logis dalam pelaksanaan demokrasi modern, namun pada akhirnya disadari bahwa individu-individu dan kelompok-kelompok warga negara seringkali merasa tidak tenwakili secara efektif oleh orang-orang yang mereka pilih secara tidak langsung. Persoalan-persoalan yang merupakan keprihatinan dan keluhan mereka seringkali tertinggal di belakang pintu para pejabat publik dan membusuk di laci-laci wakil mereka. Secara singkat representational perspective on the public ini juga dianggap tidak mencukupi untuk mengakomodasi kepentingan-kepentingan publik, baik dalam teori maupun dalam praktik administrasi publik di lapangan.

Keempat, perspektif penyedia layanan atau the services-providing perspective. Perspektif lain yang berkembang dalam ilmu sosial adalah yang memandang publik sebagai pelanggan (costumer) yang harus dilayani. Konsep ini menganggap individu sebagai pelanggan. Street-level bureaucrats mempunyai tugas untuk melayani publik yang terdiri dari individu-individu dan kelompok-kelompok. Sampai derajat tertentu penempatan status individu dan kelompok sebagai costumers dapat menggambarkan perspektif publik yang dicitakan. Oleh karena itu, perspektif ini mengharapkan agar para pejabat yang berada paling dekat dengan publik (streetlevel bureaucrats) diharapkan menjadi penyokong utama publik mereka. Para pejabat ini diharapkan menggunakan keahlian, pendidikan, dan pengetahuan mereka untuk memberikan pelayanan terbaik bagi publik. Pandangan seperti ini merupakan salah satu pintu untuk menggali kembali konsep publik sebagai titik sentral dari setiap pelayan yang dilakukan oleh pejabat publik. Akan tetapi dalam kenyataannya, street-level bureaucrats sebenarnya telah terorganisir menjadi kelompok kepentingan tersendiri. Di Indonesia dalam masa Orde Baru sampai sekarang pegawai negeri terorganisir dalam sebuah wadah yang disebut dengan Korpri (Korps Pegawai Negeri Republik Indonesia).Mereka memperjuangkan kepentingan-kepentingan melalui proses politik tertentu untuk mencapai kemenangan yang berarti yang dalam kasuskasus tertentu dilakukan dengan cara memanfaatkan publik sebagai costumer mereka. Sehingga pada akhirnya, seperti juga dalam model-model/perspektifperspektif sebelumnya, kepentingan pejabatlah yang mengemuka dan bukannya 
kepentingan publik yang seharusnya menjadi titik sentral dari setiap pusat pelayanan publik.Maka konsep publik dalam perspektif ini pun mempunyai kelemahan yang substansial.

Kelima, perspektif kewarganegaraan, the citizen perspective. Konsep kewarganegaraan merupakan salah satu pusat perhatian administrasi publik modern. Hal tersebut belum muncul dalam pembicaraan administrasi publik di dekade yang lalu. Reformasi administrasi publik di berbagai negara, khususnya negara berkembang termasuk di Indonesia akhir-akhir ini, ditandai oleh dua tuntutan penting. Pertama, tuntutan akan munculnya pelayanan-pelayanan publik yang lebih terdidik dan terseleksi dengan dasar meritokrasi. Kedua, tuntutan agar setiap warga negara diberi informasi yang cukup (well-informed) agar secara umum marak dapat aktif dalam berbagai kegiatan publik dan memahami konstitusi secara baik.Dalam berbagai literatur, konsep public dapat diidentikkan dengan konsep masyarakat warga yang merupakan padanan dari civil society.

Sumber kekuatan pendekatan kewargaan ini terutama terletak pada potensinya untuk meningkatkan dan memuliakan publik yang termotivasi oleh adanya perhatian bersama bagi kebijakan bersama. Sedangkan kelemahannya tidak terutama terletak pada konsepsi tentang publik itu sendiri, tapi lebih berkait dengan tidak memadainya berbagai kemampuan teknis. Pertama,kegagalan untuk menyadari kompleksitas isu-isu publik; kedua, kebutuhan mendesak akan keahlian yang memadai untuk memahami isu-isu publik dan kepemimpinan yang terpercaya. Ketiga, kesulitan untuk memotivasi publik untuk berpartisipasi dalam berbagai kegiatan publik.Namun demikian, sekalipun mengandung beberapa kelemahan perspektif ini telah menempatkan konsep publik pada tempat yang lebih terhormat dan tepat dibandingkan dengan perspektifperspektif lainnya.Dengan begitu lebih memberi harapan dari mana harus dimulai jika revitalisasi konsep publik harus dilakukan.

\section{Dekonstruksi "Publik" dalam Pemikiran dan Praktik Administrasi Publik di Indonesia}

Dari pelbagai pendangan mengenai konsep publik dapat dilihat kekuatan dan kelemahan masing-masing pandangan tersebut. Dan secara konseptual terlihat bahwa perspektif terakhir lebih memberikan harapan bagi revitalisasi konsep publik/public dalam bidang administrasi publik yang sekaligus juga menjadi pijakan bagi dikembangkannya kajian terhadap manajemen publik. Menurut Frederickson ${ }^{10}$ ada beberapa prinsip yang dapat diakomodasi tentang bagaimana konsep publik dapat diperkuat eksistensinya, baik sebagai ide maupun sebagai suatu seni dalam praktik.

Prinsip pertama, konsep publik harus dibangun melalui pemberdayaan konstitusi. Setiap tindakan pejabat publik harus berbasis pada konstitusi, artinya, administratur publik harus mempunyai kompetensi, baik secara teknis maupun secara moral, untuk mengabdi pada konstitusi. Oleh karena itu, yang terpenting bukanlah kemampuan pejabat publik untuk menghafal konstitusi pasal-demi-pasal, melainkan komitmen mereka untuk menjadikan konstitusi sebagai dasar dari setiap tindakannya. Ini bermakna bahwa

10. Frederickson, George. (1997). the Spirit of Administration. San Fransisco: Jossey-Bass. 
keabsahan suatu pemerintahan terutama dilegitimasi melalui tindakannya untuk menerima dan menjalankan konstitusi yang berlaku dengan tujuan pemberdayaan konstitusi dan bukan hanya ditentukan melalui proses pemilihan yang demokratis. Tindakan pejabat-pejabat pemerintahan tidak hanya diatur oleh keputusan mayoritas tetapi oleh prinsip yang ada di dalam konstitusi. Dengan demikian, tindakan pelecehan terhadap publik oleh para pejabat pemerintah dapat dihindari.

Prinsip kedua, konsep publik harus berdasarkan pada pengertian tentang warga negara yang berbudi luhur (virtouos citizen). Dalam hal ini perlu disadari bahwa suatu rezim pemerintahan tidak akan lebih baik dari masyarakat yang mereka wakili. Oleh karena itu, untuk melahirkan rezim yang baik perlu dibangun warga negara yang baik pula yang merupakan sumber dari pemerintahan tersebut. Atas dasar pemikiran tersebut, dapat diidentifikasi empat karakter yang perlu diperhatikan dalam membentuk virtuous citizen, yakni:

1. Setiap warga negara harus mengerti dokumen pendirian negara dan dapat menerapkan filsafat moral dalam menilai kebijakan-kebijakan yang dibuat oleh para pejabat.

2. Setiap warga negara diharapkan mempunyai kesopanan (civility) dengan segala aspeknya, terutama kesabaran (forbearance) dan toleransi (tolerance).

3. Setiap warga negara seharusnya mempunyai kepercayaan bahwa nilainilai yang dianut oleh rezim adalah benar dan tepat, tidak hanya sesuatu yang diterima secara mayoritas.

4. Akhirnya, setiap warga negara diharapkan mempunyai tanggung jawab moral individu sehingga apabila terdapat situasi kompromi dengan nilai-. nilai rezim, virtuous citizen dapat bertindak mempertahankan nilai-nilai yang ia anggap benar.

Prinsip ketiga, konsep publik harus didasarkan pada pembentukan dan usaha mempertahankan sistem dan prosedur untuk mendengarkan dan merespon kepentingan publik. Dalam hal ini administrasi publik hendaknya tidak hanya terikat pada efisiensi dan ekonomi, namun juga pada keadilan sosial (social equity) dan nilainilai yang lebih luas dan umum seperti yang telah disebutkan dibagian sebelumnya.

Prinsip keempat, konsep publik harus didasarkan pada kebajikan dan kasih. Jika benar bahwa tujuan pemerintahan adalah memperluas perlindungan nilai-nilai rezim kepada seluruh warga negara, maka administrasi publik harus memiliki suatu konsep tentang publik yang didasarkan pada kebajikan dan kasih sayang. Warga negara yang baik akan menghargai dan mematuhi hukum sebagai kepedulian pada kepentingan orang lain seperti pada kepentingannya sendiri. Mereka juga akan mengusahakan dengan segala kemampuannya untuk kesejahteraan seluruh warga masyarakat yang merupakan "saudaranya". Demikian pula rezim yang berkuasa akan bertindak sama, karena mereka adalah penjelmaan publik yang mendapat amanah yang perlu ditunaikan.

\section{Partisipasi Publik dalam Konstruksi Baru Administrasi Publik Ke Depan}

Partisipasi publik dapat terjadi bila ada demokrasi. Selama ini, partisipasi publik sulit terealisir karena pemerintah daerah seringkali lebih dipengaruhi oleh kepentingan pembangunan industri dan pelobi-pelobi bisnis. Biasanya masyarakat baru bereaksi keras jika ada sesuatu yang dipandang sangat bertentangan dengan kepentingan 
publik yang lebih luas. Seharụsnya masyarakat mempunyai hak agar baik pejabat yang terpilih maupun birokrasi mengakui partisipasi sebagai cara yang absah untuk menjamin bahwa perubahan yang berlangsung tidak menguntungkan kelas tertentu di atas penderitaan kelompok masyarakat lainnya.

Partisipasi publik dapat didefinisikan sebagai the continued active involvement of citizens in making the policies which affect them. "Terjadi perubahan pandangan masyarakat terhadap partisipasi.Kini, masyarakat tidak lagi memandang partisipasi publik sebagai sebuah kesempatan yang diberikan oleh pemerintah karena kemurahan hatinya. Partisipasi lebih dihargai sebagai suatu layanan dasar dan bagian integral dari local govemance. Dalam citizen-centred government, partisipasi publik merupakan alat bagi good governance. Secara filosofis, jalannya pemerintahan terfokus pada tanggung jawab masyarakat. Istilah partisipasi publik kini juga berarti keterikatan (engagement) publik secara aktif dan disengaja tidak hanya dalam proses pemilihan umum, tetapi juga dalam pembuatan keputusan kebijakan publik atau dalam penyusunan arahan strategis lainnya.

Partisipasi publik seyogyanya tidak dilihat hanya dalam sekali atau serangkaian kejadian, tetapi dilihat dalam penentuan berbagai hal penting secara bersama-sama antara politisi, administrator, kelompok kepentingan, dan warga." Pada dasarnya tujuan partisipasi publik sangatlah beragam, yakni meliputi: berbagi informasi, akuntabilitas, legitimasi, pendidikan, pemberdayaan masyarakat, hingga berbagi kekuasaan secara nyata.

Beberapa karakteristik dasar dari partisipasi publik dalam pemerintahan daerah telah dijelaskan oleh Philips dan
Graham setelah menyimpulkan beberapa studi tentang partisipasi publik dalam local govemance. Karakteristik tersebut meliputi: partisipasi publik melibatkan warga dalam keseluruhan proses pemilihan kota; partisipasi publik melibatkan individu dan kelompok, baik yang bersifat ad hoc maupun stakeholderpermanen; pada tingkatan minimum, partisipasi publik melibatkan interaksi dan komunikasi dua arah yang diikuti dengan potensi untuk mempengaruhi keputusan kebijakan dan outcomenya; partisipasi publik lebih berupa seni ketimbang ilmu karena ia berpijak pada dua realitas, yakni realitas politik (terjadi dalam lingkungan politik) dan realitas birokrasi (berada dalam konteks antar pemerintahan).

Partisipasi publik dapat berlangsung dalam beberapa area pengambilan keputusan ${ }^{12}$ yakni: pertama, praktik operasional yang menyangkut perilaku dan kinerja pegawai dalam institusi publik, isuisu yang berkaitan dengan aspek lainnya dalam kualitas pelayanan publik, keterandalan dan keteraturan pelayanan, fasilitas bagi pengguna jasa dengan kebutuhan tertentu dan lain sebagainya. Kedua, keputusan pembelanjaan yang berkaitan dengan anggaran yang didelegasikan. Anggaran yang menyangkut modal besar sampai pada anggaran pendapatan menyeluruh yang mencakup gaji pegawai dan biaya rutin bagi kantor

11. Graham, K.A., and S.D. Philips. (1998). "Making Public Participation More Effective: Issues for Local Government", dalam Graham, K.A. dan S.D. Philips, (eds.). Citizen Engagement: Lessons in Participation from Local Govemment. Toronto: Institute of Public Administration of Canada.

12. Burns, D., Hambleton, and Hoggett. (1994). The Politics of Decentralization: - Revitalising Local Democracy. London: The Mac Millan Press. 
tertentu dan pemeliharaannya termasuk peningkatan pendapatan melalui peningkatan pajak lokal. Ketiga, pembuatan kebijakan yang menyangkut tujuan-tujuan strategis dari pelayanan tertentu, rencana strategis bagi pembangunan kawasan dan fasilitas tertentu, dan prioritas pembelanjaan dan keputusan alokasi sumber daya lainnya.

Pelbagai bentuk partisipasi publik dalam Pemerintahan Daerah berdasarkan pengalaman berbagai negara di dunia dijelaskan oleh Norton, ${ }^{13}$ pertama, referendum bagi isu-isu vital di daerah tersebut dan penyediaan peluang inisiatif warga untuk memperluas isu-isu yang terbatas dalam referenda. Kedua, melakukan desentralisasi di tingkat kota (decentralization in cities) kepada unit-unit yang lebih kecil sehingga kebutuhan, tanggung jawab dan pengambilan keputusan lebih dekat lagi kepada masyarakat. Ketiga, konsultasi dan kerjasama dengan masyarakat sesuai dengan kebutuhan dan kepentingan mereka. Dan yang keempat adalah partisipasi dalam bentuk sebagai anggota yang dipilih. Semakin banyak anggota dewan yang dipilih secara proporsional dari jumlah penduduk, maka semakin tinggi partisipasi publiknya. Sebaiknya, semakin kecil rasio anggota dewan dibandingkan dengan jumlah penduduk, maka semakin besar derajat partisipasinya.

Dalam kerangka yang berbeda, Antoft dan Novack $^{14}$ juga mengungkapkan berbagai bentuk partisipasi yang bisa dilakukan oleh komunitas untuk memperjuangkan kepentingan dan kebutuhannya. Bentuknya bisa berlangsung secara simultan untuk memberikan kesempatan bagi penduduk menikmati akses partisipasi yang lebih besar karena tidak semua penduduk pada waktu yang bersamaan, di tempat yang sama, dengan kepentingan yang sama dapat berpartisipasi secara langsung dan bersama-sama. Ada kendala waktu, tenaga, dan sumber daya lainnya yang membatasi partisipasi masyarakat ini. Bentuk-bentuk partisipasi tersebut meliputi: electoral participation, lobbying, getting on council agenda, special purpose bodies, dan special purpose participation.

Namun demikian, proses mewujudkan partisipasi publik dalam pemerintahan daerah bukanlah hal yang mudah, terutama di negara-negara sedang berkembang yang baru keluar dari rezim diktator/tiran. Masyarakat belum terbiasa dengan partisipasi aktif dan sukarela, atau mereka masih terbiasa dengan mobilized participation. Oleh karena itu, upaya pemberdayaan merupakan hal krusial yang harus dilakukan. Stoker ${ }^{15}$ menuntut agar local authorities harus membuka diri disertai dengan penguatan local interest goups. Ini artinya pendekatan struktural dan kultural harus dilakukan dalam hal ini.

Sementara itu, Burns ${ }^{16} \mathrm{dkk}$., justru memulainya dari pemberdayaan masyarakat dengan mengajukan jenjang pemberdayaan warga.Jenjang tersebut dimulai dari nonpartisipasi warga, lalu ditingkatkan menjadi partisipasi warga, dan terakhir sampai pada kontrol oleh warga (citizen control). Jenjang nonpartisipasi terlihat dari bentuk layanan pemerintah daerah kepada

13. Norton, A. (1994). Intemational Handbook of Local and Regional Government: $A$ Comparative Analysis of Advanced Democracies. Cheltenham: Edwar Elgar.

14. Antoft, Kell, and Jack Novack. (1998). Grassroots Democracy: Local Govemment in the Maritimes. Nova Scotia: Henson College, Dalhousie University.

15. Stoker, G. (1991). the Politics of Local Govemment 2nd edition. London: MacMillan Education Ltd.

16. Burns, D., Hambleton, and Hoggett. (1994) op-cit. 
warga yang dimulai dari anak tangga: civic hype, cynical consultation, poor information, sampai customer care. Keterlibatan warga lebih tinggi lagi ada pada jenjang partisipasi warga yang dimulai dari anak tangga pelayanannya, berupa high quality information, genuine consultation, effective advisory board, limited decentralised decision making, partnership, sampai yang tertinggi adalah delegated control. Tingkat pemberdayaan warga yang tertinggi justru terletak pada jenjang kontrol oleh warga, yang dimulai dari anak tangga: entrusted control sampai puncaknya yaitu interdependent control.

Burns dkk. selanjutnya, menambahkan bahwa tiga jenjang pemberdayaan warga beserta anak tangganya tersebut dimaksudkan untuk memperjelas saja kondisi yang dimungkinkan. Bisa jadi, kondisi sebenarnya bisa lebih sederhana ataupun lebih rumit dari kerangka tersebut. selain itu, realitas yang kompleks dari partisipasi warga bisa bervariasi antara institusi publik yang satu dengan yang lainnya sesuai dengan tuntutan situasi dan kebutuhan yang aktual. Jenjang dan anak tangga pemberdayaan tersebut tidak mesti harus diperlakukan sebagai cara preskriptif dalam meningkatkan derajat pemberdayaan publik. Hal tersebut juga tidak perlu diperlakukan sebagai cara bertahap yang harus dilampaui satu persatu untuk mencapai anak tangga tertinggi. Sesuai dengan situasi dan prinsip kehati-hatian, maka melompati anak tangga pada antarjenjang bisa dilakukan sepanjang memungkinkan sesuai dengan kesiapan institusi.Setiap organisasi publik seyogyanya berupaya mencapai jenjang yang tertinggi untuk meningkatkan keberdayaan dan keterlibatan publik dalam pemerintahan daerah.

Berdasarkan penjelasan tersebut,maka menjadi jelas mengapa partisipasi publik yang tertuang secara implisit dalam UUNo. 22/1999 ternyata sangat terbatas dan membatasi. Masyarakat hanya sebatas berinteraksi dengan politisi di DPRD yang harus menampung (termasuk memperhatikan dan menyalurkan aspirasi, menerima keluhan dan pengaduan masyarakat) dan menindaklanjuti (termasuk memfasilitasi tindak lanjut) aspirasi daerah dan masyarakat. Tidak ada penjelasan mengenai mekanisme yang bisa dijadikan pedoman dan jaminan bagi pengakuan dan terselenggaranya partisipasi publik. Siapa yang boleh dan harus terlibat, bagaimana bentuk keterlibatannya, apa konsekuensi keterlibatannya, apa yang harus dilakukan oleh DPRD dan Kepala Daerah beserta perangkatnya, apa sanksi atas kelalaian dalam pengabaian partisipasi publik, apa hak dan kewenangan publik atas pejabat yang dipilihnya, dan lain sebagainya.

Dengan menimbang perbandingan bobot policy content yang terkandung dalam kebijakan tersebut, maka dapat dikatakan bahwa tidak ada pengakuan yang nyata bahwa stakeholder utama dalam pemerintahan daerah adalah masyarakat. Tampaknya pengakuan lebih berat timbangannya kepada pemerintah daerah, baik itu DPRD maupun Kepala Daerah beserta perangkatnya. Bentuk partisipasi yang dinyatakan secara implisit hanyalah sekedar masukan bagi pengambilan keputusan dan keluhan untuk menyatakan kebutuhan. Namun demikian, mekanismenyapun tidak jelas.

Terdapat dua metode utama partisipasi yang diakui oleh UU tersebut, yakni pertama, masuknya anggota masyarakat sebagai elected member dari DPRD dan Kepala Daerah, serta yang kedua, desentralisasi kepada unit yang lebih rendah, yakni Desa. Khusus untuk yang 
pertama, anggota DPRD yang dimaksudkan untuk mewakili kepentingan konstituennya, karena sistem pemilu yang dipergunakan membuat mereka lebih berperan sebagai kepanjangan tangan partainya. Sekali lagi, wujud partisipasi warga melalui elected member ini disinyalir telah gagal dan tetap menempatkan warga pada posisi lemah dalam menyalurkan aspirasi dan tuntutan lokalnya dalam pemerintahan daerah.

\section{Penutup}

Administrasi publik adaiah sebuah disiplin ilmu, profesi, dan seni. Oleh karena itu, dalam menatap serta menerapkan reformasi administrasi publik ke depan bangsa ini harus mulai memahami pelbagai fenomena dan nomena administrasi publik dengan berbagai wajah/dimensi. Misalnya mengubah orderparadigmmenjadi apa yang disebut oleh Yong A. Lee ${ }^{17}$ sebagai chaos paradigm. Karena beban dunia administrasi tidaklah seteratur seperti yang dibayangkan. Kehebohan/ketungganglanggangan globalisasi, massifnya inetervensi negara luar ke dalam batas-batas demarkasi suatu bangsa, hingga terbuka arus informasi seterbuka-bukanya menuntut pemahaman yang tidak biasa. Karenanya, tiga rekomendasi yang diberikan oleh Leach, Stewart, dan Walsh $^{18}$ mengenai hubungan antara pemerintah dan warga negara perlu dicemati lebih dalam. Ketiga hal tersebut ialah: the residual enabling authoritymenggabungkan penekanan pada strong market dengan peran pemerintah daerah yang lemah dan berdiri di atas bentuk demokrasi yang netral baik terhadap bentuk representative democracy maupun participatory democracy. Istilah residu mengacu pada posisi pemerintah daerah sebagai 'provider of last resort', yang bertanggung jawab pada pelayanan yang terbatas saja, yakni pelayanan yang tidak dapat disediakan secara langsung oleh pasar swasta maupun mekanisme lainnya. Konsep enabler-nya berupa pemerintah daerah diharapkan membuat spesifikasi layanan publik, lalu melakukan contracting out pada kontraktor swasta atau, bila tidak memungkinkan, pada badan-badan internal pemerintah daerah lainnya, lalu memonitor kinerja kontraktor tersebut. Dalam hal ini, dasar ideologinya adalah bahwa pasar diyakini sebagai mekanisme yang paling efisien dan efektif dalam menyediakan barang dan layanan publik, dengan sedikit pengecualian dan regulasi yang terbatas.

The market-oriented enabling authority merupakan kombinasi dari penekanan pada strong market, dengan peran pemerintah daerah yang kuat, disertai penekanan pada demokrasi partisipatif. Seperti halnya model residual authority, model ini mengutamakan pasar dalam urusan pemerintah daerah, namun berbeda dalam starting-pointnya. Pemerintah daerah mempunyai peran yang kuat dan aktif dalam menentukan masa depan perekenomian di wilayahnya. Pemerintah daerah dipandang sebagai badan koordinasi dan perencanaan kunci bagi pembangunan ekonomi daerah, dengan menyediakan mekanisme dan insentif sehingga perekonomian dapat berkembang. Hubungan antara pemerintah daerah dengan agen-agen perekonomian daerah dilihat sebagai proses dua arah, dengan tanggung jawab sosial ditekankan pada kesepakatan perencanaan antara

17. Lee, Yong A.. (1996). An Agenda for Public Administration in Postmodern Era: the Search for Order out of Chaos. Korean Review of Public Administration 1(1): 1-28, 1996.

18. Leach, S., J. Stewart, and K. Walsh. (1994). The Changing Organization and Management of Local Government. London: MacMillan Press. 
pengembang dan pemerintah daerah dan dinegosiasikan secara aktif. Peran pemerintah daerah adalah memberanikan dan mendukung perusahaan swasta. Upaya-upaya yang dilakukan adalah dengan menegosiasikan kontrak yaing memberikan manfaat maksimal bagi pemerintah daerah. Peran utamanya justru terletak pada titik sentral dalam suatu jaringan eksternal, terutama sektor swasta dalam menyediakan barang dan memberikan layanan publik.

The community-oriented enabling authority, yang merupakan gabungan dari penekanan pada demokrasi partisipatif yang kuat, dan setidak-tidaknya ada di posisi tengah dalam hubungannya dengan weak or strong local govemance, serta penekanan antara sektor publik dan pasar.Tujuan utamanya adalah memenuhi kebutuhan pendudukyang beragam dengan menggunakan saluran penyediaan layanan apa saja (apakah itu penyediaan langsung pemerintah, sektor swasta, organisasi nirlaba, atau sekedar pengaruh belaka) yang dipandang paling tepat. Penekanannya terletak pada kebutuhan kolektif ketimbang perseorangan, pada penduduk daerah yang memiliki peran sebagai konsumen maupun pelanggan. Model ini berimplikasi pada tuntutan adanya participatory democracy dan community accountability. Pemerintah daerah dituntut untuk outward-looking. Pada prinsipnya, model terakhir ini dapat berjalan baik dalam pemerintah daerah yang kuat maupun lemah, atau dalam sektor publik yang kuat maupun pasar yang kuat. Namun demikian, model ini kurang sesuai dalam pemerintah daerah yang lemah dengan pasar yang kuat seperti halnya residual model.

Di antara tiga model alternatif ini, maka model community-oriented enabler merupakan model yang paling sesuai bagi pemerintah daerah yang berorientasi pada kebutuhan masyarakat. Alternatif pilihan organisasi internal pemerintah daerah yang cocok dalam model ini antara lain manajemen matriks, desentralisasi, departementasi berbasis wilayah (bukan berbasis profesi), dan kerjasama antar profesi. Model ini memperlakukan adanya strategic centeryang kecil tapi berpengaruh. Seperti halnya dalam market-oriented enabler, dibutuhkan pula political executive yang kuat namun lebih memberikan ruang yang lebih besar bagi demokrasi partisipatif.

Strategi utama model ini adalah mengenali semua kebutuhan masyarakat secara menyeluruh. Pemerintah daerah tidak secara langsung memenuhi seluruh kebutuhan tersebut, kecuali dalam lingkup strategic management lalu aspek operasionalisasinya diserahkan kepada masyarakat. Masyarakat berpartisipasi dalam lingkup pengambilan keputusan, pelaksanaan keputusan, dan local advocacy.' Maksudnya adalah agar penyediaan layanan publik mengikuti kebutuhan dan preferensi masyarakat dengan membiarkan mereka menjalankan peran aktif dalam semaksimal mungkin dalam penyediaan layanan publik. Sebagai local community dalam penyediaan layanan publik ini tidak semata-mata penduduk lokal tetapi juga meliputi agen-agen lokal seperti sektor swasta, organisasi nirlaba, sektor publik lainnya dan yang sejenisnya.

Dengan memahami model ini, tampak bahwa tipe yang lebih ideal bagi pemerintahan daerah di Indonesia adalah community-oriented enabler authority. Pemerintah daerah seyogyanya telah mulai outward looking tidak lagi inward looking seperti selama ini. Kebutuhan nyata dalam pemerintahan daerah adalah kebutuhan masyarakat bukan kebutuhan internal pemerintah daerah sendiri. Keberadaan pemerintah daerah adalah untuk memenuhi 
dan mengurus fungsi lokal untuk memenuhi kebutuhan dan kepentingan masyarakat setempat.

Demokrasi partisipatif sebagaimana dituntut oleh reformasi juga hendaknya segera direalisasi dengan tidak mengalihkannya kepada demokrasi perwakilan yang manipulatif. Anggota dewan yang dipilih adalah mereka yang berjuang untuk kepentingan aspirasi konstituennya dan tidakmemanipulasi aspirasi tersebut dengan lebih patuh kepada dan mendahulukan kepentingan partai.Rakyatlah yang sebenarnya memilih bukan semata-mata partai politiknya.

Untuk mewujudkan model ideal ini maka tidak ada jalan lain selain diperkuat melalui perundang-undangan mengenai pemerintahan daerah. Berbagai macam persoalan yang muncul dan terus akan timbul dalam pemerintahan daerah selama ini karena undang-undang yang memuat kebijakan pemerintahan daerah kurang mampu menyerap aspirasi yang sesungguhnya dari kehendak masyarakat dalam terlibat sebagai aktor utama dalam sistem pemerintahan dan pembangunan daerah. Untuk itu, revisi UU 22/1999 memang perlu dilakukan agar mampu mencakup partisipasi masyarakat yang sebenarnya. Dengan memperoleh kebijakan yang baik, maka berarti satu masalah telah selesai sehingga mampu mengurangi potensi masalah yang akan muncul serta mengembangkan kemampuan memecahkan masalah di masa mendatang.

\section{Daftar Pustaka}

Antoft, Kell, and Jack Novack, 1998. Grassroots Democracy:Local Government in the Maritimes. Nova Scotia: Henson College, Dalhousie
University.

Burns, D., Hambleton, and Hoggett, 1994. The Politics of Decentralization: Revitalising Local Democracy. London: The Màc Millan Press.

Casper, Gretchen, and Michelie Taylor, 1996. Negotiating Democracy: Transition from Authoroitarian Rule. Pittsburgh: Pittsburgh Press.

Cope, Glen Hahn, 1997. Bureaucratic reform and Issues of Political responsiveness. Journal of Public Administration Reaserch and Theory $7(3)$ : 461—471, July 1997.

Dimock and Dimock, 1969. Public Administration. New York: Rinehart \& Co.

Frederickson, George,1997. the Spirit of Administration.San Fransisco: Jossey-Bass.

Graham, K.A., and S.D. Philips. 1998. "Making Public Participation More Effective: Issues for Local Government", dalam Graham, K.A. dan S.D. Philips, (eds.). Citizen Engagement: Lessons in Participation from Local Government. Toronto: Institute of Public Administration of Canada.

Huntington, Samuel P. ,1971. "Change to Change: Modernization, Development, and Politics". Comparative Politics, III: 283—322, April 1971.

Leach, S., J. Stewart, and K. Walsh, 1994. The Changing Organization and Management of Local Govemment. 
Partisipasi Publik dalam Proses Menuju Indonesia Baru Evaluasi...; Leo Agustino

London: MacMillan Press.

Lee, Yong A., 1996. An Agenda for Public Administration in Postmodern Era: the Search for Order out of Chaos. Korean Review of Public Administration 1(1): 1-28, 1996.

Norton, A.,1994. Intemational Handbook of Local and Regional Govemment: A Comparative Analysis of Advanced Democracies. Cheltenham: Edwar Elgar.

O'toole, Laurence., Jr.,1997. the implications for democracy in a Networked Bureucratic World. Journal of Public Administration Reaserch and Theory7(3): 443-459, July 1997.
Snyder, Jack. (2003). Dari Pemungutan Suara ke Pertumpahan Darah: Demokratisasi dan Konflik Nasionalis. Jakarta: Gramedia.

Stoker, G.,1991. the Politics of Local Government 2nd edition. London: MacMillan Education Ltd.

Sun, Tung-Wen and John J. Gargan. (1996). A Strategic Perspective on Public Administration Problems in Taiwan. Asian Joumal of Public Administration 18(1): 96-118, June 1996.

Wolf, Patrick, 1997. "Why Must we Invent the Federal Government? Putting Historical Development Claims to the Rest". Journal of Public Administration Reaserch and Theory 7(3): 353388, July 1997. 